\title{
Impact of oil prices on profitability and investment activity of oil companies from central and eastern europe
}

\author{
A.Ilic, T. Ponomarenko \\ Department of Organization and Management, Saint Petersburg Mining University, St. \\ Petersburg, Russia
}

\begin{abstract}
In this text, we analyze the profitability and investments trends of oil companies from Central and Eastern Europe $\left(\mathrm{CEE}^{1}\right)$ over the period 2008-2019. Based on descriptive statistics, comparative analysis, and panel data analysis, we show that: (1) CEE oil companies increased profitability in the period 2008-2019; (2) in the second sub-period (2015-2019), when the oil price was lower, ROACE of CEE oil companies exceeded ROACE of global major oil and gas companies; (3) in the second sub-period investment activity continued to be relatively high; and (4) oil price had less influenceon profitability and investment activities of CEE oil companies in comparison to oil majors. It is also showed that the upstream segment is less important for CEE oil companies than for major oil companies and the contribution of upstream segment to profitability of the companies was reduced during the period of lower oil prices.
\end{abstract}

\section{Introduction}

According to different researches, for example, [1] or [2], global oil companies are facing increased challenges due to the fast-changing energy environment. Apart from traditional challenges, such as new sources of growth, the volatility of oil prices, pressure on the improvement of oil technology, and limited availability of oil and gas reserves, they are facing now a new challenge of energy transition - a gradual shift from hydrocarbons and nuclear energy to renewable energy sources (transition from oil companies to diversified energy companies).

\footnotetext{
${ }^{1}$ Central and Eastern Europe usually includes countries of the former Eastern Block: Poland, Czech Republic, Slovakia, Hungary, Romania, Bulgaria, Serbia, Slovenia, Croatia, Bosnia and Herzegovina, Montenegro, North Macedonia, Albania, Estonia, Latvia, and Lithuania. Due to the close proximity and strong focus on CEE business activities, we included two more countries in our analysis, i.e., Austria and Greece and their largest oil companies OMV and Hellenic Petroleum.
} 
However, in the recent period,the focus of research of scholars was on issues related to general sustainability of the business model (see, for example, [3]) andenergy transition, questions related to environmental issues and, in particular, new technologies, such as carbon capture and storage (see, for example, [4,5]), questions related to digitalization and industry 4.0 (see, for example, [6]) and questions related to some conceptual approaches for investments in oil \& gas industry [7], while less emphasis was put on the dynamics of oil prices.

In such an environment, it is interesting to analyze trends in profitability and investments of oil companies and how they adapt to new conditions. Bearing in mind the high volatility of oil prices over the last couple of years, it is important to understand how those changes affected the profitability and investments of oil companies.

These indicators are very important for their strategic development, in particular, for the formulation of an adequate product portfolio in the future. Setting the right portfolio is one of the most important strategic challenges, and more and more oil companies stress this in their official documents. For example, in their annual report for 2019, Hungarian oil company MOLemphasizes that the company is in a continuous process of developing its future product portfolio, launching new products and services that not only mitigate transition risk but capitalize on opportunities created by it, positioning the group to meet future demand for cleaner fuel, energy-efficient and recycled products, clean and sustainable mobility solutions and renewable energy, to remain competitive in a carbon-constrained economy ${ }^{2}$. GreekoilcompanyHellenic Petroleum stressesinoneofthe reportsthatthestrategicgoalistofacilitate the energy transition in the Eastern Mediterranean by maximizing returns in core business and developing a diversified, best in the class energy portfolio ${ }^{3}$. In that context, one of the essential questions is what will be the role of the upstream segment in the future product portfolio of oil companies.

Inthisarticle, we analyze trends of profitability and investments of oil companies of CEE. In particular, we pay attention to the following: (1)are there any changes in profitability in the 2008-2019 period; (2) how the dynamics of crude oil prices affect profitability and investments, and (3) what is the role of oil and gas upstream related to profitability and investments and whether there are any implications for the future growth of this business segment.

\section{Review of the literature}

There is literature dealing with theanalysisofprofitabilityandinvestmentsofoilcompanies, the impactofoilpricesontheresults,strategicobjectives, and challengesof oil companies, but it is mainly focused on the global oil companies, while the literature dedicated to the CEE region is relatively weak.

Analyzingtheliterature ontheimpactofoilpricesonoilcompanies [8],we see that compared to the literature on the impact on oil prices on oil company stocks, the literature on the analysis of the impact on oil prices by financial results is relatively

\footnotetext{
${ }^{2}$ https://molgroup.info/storage/documents/publications/annual_reports/2019/mol group integrated annual report 2019 eng.pdf

${ }^{3} \mathrm{https}: / / w w w . h e l p e . g r /$ userfiles/10beb747-86d7-4c1c-a1e1a2850113ee26/ELPE\%20Results\%20\%20Presentation\%20\%20$\% 204 \mathrm{Q} \% 202019$ 1.pdf
} 
limited and ambiguous. In their work, the authors analyzed the impact of oil prices on eight major oil companies in the period 2012-2016 and founded that crude oil prices hada positive and significant impact on the accounting returns (as represented by ROA, ROE, and EPS) of the firms considered, [9] showedthat crude oil prices positively and significantly impact the performance of oil and gas firms in North America using accounting measures of performance and that the recent financial crises of 2007 and 2008 negatively influenced oil prices and the financial performance of oil and gas firms. In [10] investigated the financial results of oil and gas companies in the period 2006-2011 andfoundthat that return on asset, return on equity, current ratio, and quick ratio indicate significant difference performance during the period before and after the global crisis.

In [11] showedthatintheperiod 2007-2011 the total revenues and net incomes of the five major oil companies followed the pattern of oil prices. However, the companies' production of both crude oil and natural gas, their two key products, remained largely unchanged in the face of volatile prices, suggesting that for these firms, market price and the production of key products are not closely related. During the period 2007 to 2011, the five major companies' upstream activities of exploration and production contributed more to the total profitability of the firms than the downstream activities of refining and marketing.

In [12] examined the effect of crude oil prices on sector profitability using data from Thai stock exchanges from 2001 to 2010 and concluded that oil prices had a significant impact on earnings in the energy and food sectors. In [13] analyzed four large oil companies (BP, Exxon Mobil, Chevron, and Royal Dutch Shell) in the period 2009-2014. The analysis included financial analysis, energy ratio analysis, and data coverage analysis (DEA). The research results showed that of the four companies analyzed, three showed a satisfactory level of productivity. However, among all these corporations, the results confirmed that Exxon Mobil was the most outstanding.

Analyzing the relationship between investment and uncertainty in the oil and gas industry, [14], found that uncertainty in the oil market reduces investment only when it is caused by a shock to global (consumer) oil demand.

All of the above-mentioned literature sources relate mostly to the analysis of big oil companies. Our work aims at filling the gap related to the analysis of CEE oil companies and the impact of oil prices on their profitability and investment trends.

\section{Research methods and materials}

In this article we analyze the profitability and investment trends of oil companies from Central and Eastern Europe (CEE) during the period 2008-2019 and, in particular, answer the following questions: (1) to extent to which the price of crude oil affects the profitability and investments of these companies, (2) is there any difference during periods of high and low prices, (3) what are the trends in the profitability of CEE oil companies compared to major oil and gas companies, and (4) what is the role of the oil and gas upstream segment and what are its prospects for the future.

The research sample consists of eight companies from Central and Eastern Europe (“CEE”): PKN Orlen (Poland), OMV (Austria), MOL (Hungary), Hellenic Petroleum (Greece), OMV Petrom (Romania), INA (Croatia), Petrol (Slovenia) and 
NIS (Serbia). Companies are important market players in 12 countries: Poland (PKN Orlen), Czech Republic (PKN Orlen through the Unipetrol affiliate company), Slovakia (PKN through the Unipetrol affiliated company and MOL through the Slovnaft affiliated company), Lithuania (PKN Orlen through its affiliated company Orlen Lietuva, formerly Mažeiku Nafta), Austria (OMV), Hungary (MOL), Slovenia (Petrol), Croatia (INA), Romania (OMV Petrom), Greece (Hellenic Petroleum), Serbia (NIS) and Bosnia and Herzegovina (INA), NIS, OMV), and these countries cover $89 \%$ of the CEE region in terms of population. In addition to the above, CEE also includes Bulgaria, Montenegro, Northern Macedonia, Albania, Estonia, and Latvia (a total of 18 countries).

We conduct research based on the following methodology: (1) descriptive statistics based on profitability and investment indicators, (2) comparative analysis, where we compare the results of eight oil companies in Central and Eastern Europe with six major global oil and gas companies: Royal Dutch Shell, ExxonMobil, British Petroleum, Total, Chevron and ENI ("BIG"), and (3) regression of the panel data, with the help of which we try to understand the influence of the price of crude oil on the profitability and investments of oil companies. We included major oil and gas companies in the analysis for two reasons: (1) we want to see how the world's leading companies are responding to the new market environment, and (2) these companies are mainly focused on the upstream business segment and we wanted to see how the new market conditions particularly affect this segment.

As an indicator of profitability, we use ROACE - Return On Average Capital Employed since this indicator is especially useful when comparing companies in capital-intensive industries, such as oil and gas, utilities, and telecommunications. In panel regression analysis, we test ROACE and Investment based on these equations:

$$
\text { ROACEit }=a+b^{*} \text { crude oil price }+\varepsilon i t \text {, }
$$

INVESTMENTit $=\mathrm{a}+\mathrm{b}^{*}$ crude oil price $+\varepsilon i t$

As the main sources, we use the reports of the relevant international organizations and annual and other reports of selected oil companies. The analysis period is 2008-2019, but due to the strong drop in oil prices in 2014-2015, we analyze two sub-periods: 2008-2014 and 2015-2019. The average price in the first sub-period was $\$ 96$ per barrel, while in the second period the average price was $\$$ 57 per barrel $^{4}$.

\section{Results AND ANALYSIS}

During the period 2008-2019, ROACE indicator shows a high level of volatility which is presented in Figure 1.

\footnotetext{
${ }^{4}$ https://www.eia.gov/dnav/pet/hist/RWTCD.htm
} 


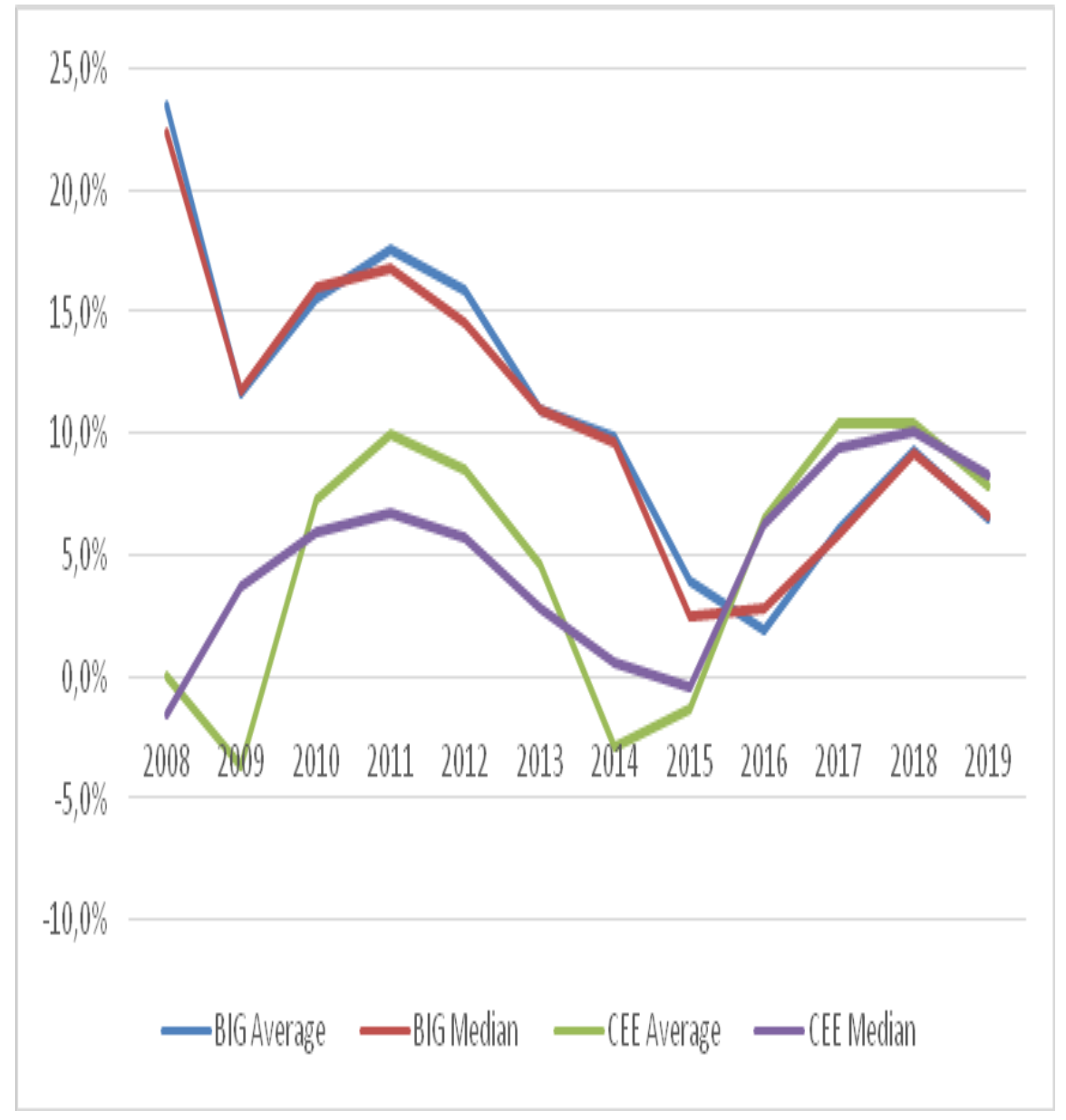

Fig.1. Return on Average Capital Employed (ROACE) for Oil Majors and CEE Oil Companies.

Source: Calculations of authors based on data from the annual reports of the selected companies.

Based on the analysis of the average and median values of ROACE of eight CEE companies ("CEE") and six major oil and gas companies ("BIG"), we see the large volatility of major companies and the difference in results in the sub-periods. In the first sub-period, the average ROACE of large oil companies was $15.1 \%$, and the average ROACE of CEE companies was $3.4 \%$. In the second sub-period, the average ROACE for large oil companies was $5.6 \%$, and the average ROACE for oil companies in Central and Eastern Europe was 6.8\%. During this period, CEE companies increased profitability and became more profitable than large companies in the period of relatively low prices (the average price in the period 2015-2019 was below \$ 60 per barrel).

During the reporting period, investments of CEE oil companies in dollar terms also fluctuated, and they decreased by about $20 \%$ in 2014 compared to 2008 . However, in 2019, compared with 2014, investments were at the same level (Table 1). 
Table 1. Investments of CEE oil companies [in USD mln].

\begin{tabular}{|c|c|c|c|c|c|c|c|c|c|c|}
\hline & \multicolumn{5}{|c|}{ Total Investments } & \multicolumn{5}{|c|}{ Upstream Investments } \\
\hline & 2008 & 2014 & 2019 & $\begin{array}{c}\Delta \\
14 / 0 \\
8 \\
\end{array}$ & $\begin{array}{c}\Delta \\
19 / 1 \\
4 \\
\end{array}$ & $\begin{array}{c}200 \\
8\end{array}$ & $\begin{array}{c}201 \\
4\end{array}$ & $\begin{array}{c}201 \\
9\end{array}$ & $\begin{array}{c}\Delta \\
14 / 0 \\
8 \\
\end{array}$ & $\begin{array}{c}\Delta \\
19 / 1 \\
4 \\
\end{array}$ \\
\hline \multirow{3}{*}{ PKN Orlen } & 1,64 & 1,19 & 1,42 & - & & & & & & \\
\hline & 0 & 9 & 1 & $27 \%$ & $19 \%$ & 0 & 158 & 156 & $\mathrm{n} / \mathrm{a}$ & $-1 \%$ \\
\hline & 5,21 & 5,07 & 5,50 & & & 3,42 & 3,91 & 3,44 & & - \\
\hline \multirow[t]{2}{*}{ OMV } & 9 & 7 & 3 & $-3 \%$ & $8 \%$ & 5 & 0 & 2 & $14 \%$ & $12 \%$ \\
\hline & 3,37 & 2,29 & 2,26 & - & & & 1,41 & & 229 & - \\
\hline \multirow{4}{*}{$\begin{array}{c}\text { MOL } \\
\text { Hellenic Petro- } \\
\text { leum }\end{array}$} & 0 & 2 & 1 & $32 \%$ & $-1 \%$ & 428 & 0 & 360 & $\%$ & $74 \%$ \\
\hline & & & & - & & & & & & \\
\hline & 497 & 180 & 270 & $64 \%$ & $50 \%$ & 0 & 0 & 0 & $\mathrm{n} / \mathrm{a}$ & $\mathrm{n} / \mathrm{a}$ \\
\hline & 2,36 & 1,86 & & - & - & 1,66 & 1,59 & & & - \\
\hline \multirow[t]{2}{*}{ OMV Petrom } & 8 & 0 & 996 & $21 \%$ & $46 \%$ & 2 & 4 & 770 & $-4 \%$ & $52 \%$ \\
\hline & & & & - & & & & & 50 & - \\
\hline INA & 857 & 294 & 325 & $\begin{array}{c}66 \% \\
-\end{array}$ & $11 \%$ & 536 & 191 & 104 & $64 \%$ & $46 \%$ \\
\hline Petrol & 207 & 78 & 136 & $63 \%$ & $\begin{array}{c}76 \% \\
-\end{array}$ & 0 & 0 & 0 & $\begin{array}{l}\mathrm{n} / \mathrm{a} \\
906\end{array}$ & $\mathrm{n} / \mathrm{a}$ \\
\hline \multirow[t]{2}{*}{ NIS } & 244 & 445 & 401 & $82 \%$ & $10 \%$ & 29 & 296 & 203 & $\%$ & $31 \%$ \\
\hline & 14,4 & 11,4 & 11,3 & - & & 6,08 & 7,55 & 5,03 & & - \\
\hline \multirow[t]{2}{*}{ Total } & 01 & 24 & 13 & $21 \%$ & $-1 \%$ & 1 & 9 & 6 & $24 \%$ & $33 \%$ \\
\hline & 1,80 & 1,42 & 1,41 & - & & & & & 216 & - \\
\hline Average & $\begin{array}{c}0 \\
1,24\end{array}$ & 8 & 4 & $\begin{array}{c}24 \% \\
-\end{array}$ & $13 \%$ & 760 & 945 & 630 & $\%$ & $36 \%$ \\
\hline Median & 9 & 822 & 698 & $29 \%$ & $10 \%$ & 229 & 244 & 180 & $14 \%$ & $39 \%$ \\
\hline
\end{tabular}

Source: Data from annual reports of oil companies

In the first sub-period, investments in the upstream business segment grew mainly due to larger investments of companies that had a relatively weak presence in this segment, such as PKN Orlen, MOL, and NIS. On the other hand, investment in the upstream in the second sub-period decreased by almost a third.

Investments of major oil and gas companies in the period 2008-2019 went in the opposite direction. In the first sub-period, large oil and gas companies invested heavily, mainly due to investments in production, and in the second sub-segment, these companies significantly reduced their total investment and, especially, investment in production, by about $50 \%$ (Table 2 ).

Table 2. Investments of major oil \& gas companies [in USD mln].

\begin{tabular}{|c|c|c|c|c|c|c|c|c|c|c|}
\hline & \multicolumn{5}{|c|}{ Total Investments } & \multicolumn{5}{|c|}{ Upstream Investments } \\
\hline & 2008 & 2014 & 2019 & $\begin{array}{c}\Delta \\
14 / \\
08 \\
\end{array}$ & $\begin{array}{c}\Delta \\
19 / \\
14 \\
\end{array}$ & 2008 & 2014 & 2019 & $\begin{array}{c}\Delta \\
14 / 0 \\
8 \\
\end{array}$ & $\begin{array}{c}\Delta \\
19 / \\
14 \\
\end{array}$ \\
\hline & 31,42 & 37,33 & 22,97 & 19 & 38 & 28,25 & 31,29 & 11,0 & 11 & 65 \\
\hline RD Shell & 1 & 9 & 1 & $\%$ & $\begin{array}{c}\% \\
-\end{array}$ & 7 & 3 & 75 & $\%$ & $\begin{array}{c}\% \\
-\end{array}$ \\
\hline Exxon- & 26,14 & 38,53 & 31,14 & 47 & 19 & 19,73 & 32,72 & 23,4 & 66 & 28 \\
\hline Mobil & 3 & 7 & 8 & $\begin{array}{c}\% \\
-\end{array}$ & $\begin{array}{c}\% \\
-\end{array}$ & 4 & 7 & 85 & $\begin{array}{l}\% \\
-\end{array}$ & $\begin{array}{c}\% \\
-\end{array}$ \\
\hline $\begin{array}{c}\text { British } \\
\text { P }\end{array}$ & $\begin{array}{c}30,70 \\
0\end{array}$ & 23,78 & 19,42 & 23 & 18 & $\begin{array}{c}22,20 \\
0\end{array}$ & 19,77 & $\begin{array}{c}11,9 \\
04\end{array}$ & 11 & 40 \\
\hline
\end{tabular}




\begin{tabular}{|c|c|c|c|c|c|c|c|c|c|c|}
\hline \multirow[b]{2}{*}{ Total } & 20,06 & 30,50 & 19,23 & 52 & 37 & 13,92 & 26,52 & 8,99 & 90 & 66 \\
\hline & 2 & 9 & 7 & $\%$ & $\%$ & 4 & 0 & 2 & $\%$ & $\%$ \\
\hline \multirow[b]{2}{*}{ Chevron } & 22,77 & 40,31 & 20,99 & 77 & 48 & 18,36 & 37,11 & 17,8 & 102 & 52 \\
\hline & 5 & 6 & 4 & $\begin{array}{c}\% \\
-\end{array}$ & $\begin{array}{c}\% \\
-\end{array}$ & 1 & 5 & 24 & $\%$ & $\begin{array}{c}\% \\
-\end{array}$ \\
\hline \multirow[b]{2}{*}{ ENI } & 21,42 & 14,81 & & 31 & 37 & 13,58 & 13,45 & 7,83 & & 42 \\
\hline & 6 & 0 & 9,377 & $\%$ & $\%$ & 2 & 5 & 2 & $-1 \%$ & $\%$ \\
\hline \multirow[b]{2}{*}{ Total } & 152,5 & 185,2 & 123,1 & 21 & $\overline{34}$ & 116,0 & 160,8 & 81,1 & 39 & $\overline{50}$ \\
\hline & 27 & 92 & 48 & $\%$ & $\%$ & 58 & 82 & 12 & $\%$ & $\%$ \\
\hline \multirow{3}{*}{ Average } & 25,42 & 30,88 & 20,52 & 24 & 33 & 19,34 & 26,81 & 13,5 & 43 & 49 \\
\hline & 1 & 2 & 5 & $\%$ & $\%$ & 3 & 4 & 19 & $\%$ & $\%$ \\
\hline & 24,45 & 33,92 & 20,20 & 33 & 37 & 19,04 & 28,90 & 11,4 & 38 & 47 \\
\hline Median & 9 & 4 & 8 & $\%$ & $\%$ & 8 & 7 & 90 & $\%$ & $\%$ \\
\hline
\end{tabular}

Source: Data from annual reports of oil companies

A panel study shows that oil prices positively affect the profitability of BIG oil and gas companies and the investments of BIG and CEE. The effect of oil prices on the profitability of CEE oil companies is not statistically significant. The results are presented in Table 3.

Table3. Statistics of the Panel Data Analysis.

\begin{tabular}{ccccc}
\hline & \multicolumn{2}{c}{ ROACE } & \multicolumn{2}{c}{ Investments } \\
& CEE & BIG & CEE & BIG \\
\hline p-value of crude oil price & 0.818 & 0.000 & 0.004 & 0.000 \\
$\mathrm{R}^{2}$ & 0.001 & 0.465 & 0.090 & 0.462 \\
Adjusted $\mathrm{R}^{2}$ & -0.091 & 0.416 & 0.006 & 0.412 \\
F-statistics & 0.053 & 56.589 & 8.555 & 55.785 \\
\hline
\end{tabular}

Source: Calculations of the authors based on the data from the annual reports of the selected companies

The influence of oil prices on the profitability and investments of major oil and gas companies was relatively strong since almost $50 \%$ of the results can be explained by changes in oil prices. At the same time, only about $10 \%$ of investments by CEE companies can be explained by changes in oil prices, while the impact of oil prices on the ROACE of CEE oil companies is statistically insignificant.

Analysis at the company level shows differences in the effect of oil prices on the profitability of oil companies in CEE. Of the eight companies, five show a relatively high correlation with oil prices, and for them, a relatively significant part of the profitability can be explained by changes in oil prices (21-38\%). For two of them, oil prices negatively affected profitability, and for three - positively (Table 4).

Table 4. CorrelationandR ${ }^{2}$ between ROACE oil prices during the period 2008-2019: CEE oil companies.

\begin{tabular}{ccccc}
\hline & $\begin{array}{c}\text { Average } \\
2008-2019\end{array}$ & $\begin{array}{c}\text { Median } \\
2008-2019\end{array}$ & $\begin{array}{c}\text { Correlation } \\
\text { to oil price }\end{array}$ & $\begin{array}{c}\mathrm{R}^{2} \text { to oil } \\
\text { price }\end{array}$ \\
\hline PKN Orlen & $5.6 \%$ & $6.9 \%$ & -0.62 & 0.38 \\
OMV & $6.4 \%$ & $9.0 \%$ & 0.59 & 0.34
\end{tabular}




\begin{tabular}{ccccc} 
MOL & $4.2 \%$ & $5.0 \%$ & -0.09 & 0.01 \\
Hellenic Petroleum & $1.9 \%$ & $3.5 \%$ & -0.62 & 0.39 \\
OMV Petrom & $9.9 \%$ & $10.1 \%$ & 0.62 & 0.38 \\
INA & $-0.2 \%$ & $1.9 \%$ & -0.16 & 0.02 \\
Petrol & $5.0 \%$ & $5.7 \%$ & -0.32 & 0.01 \\
NIS & $6.1 \%$ & $8.6 \%$ & 0.46 & 0.21 \\
\hline Average & $4.8 \%$ & $6.3 \%$ & 0.05 & 0.00 \\
Median & $5.3 \%$ & $6.3 \%$ & -0.25 & 0.06 \\
\hline
\end{tabular}

Source: Calculations of the authors based on the data from the annual reports of the selected companies

Unlike companies in Central and Eastern Europe, the profitability of each major oil and gas company BIG shows a positive, fairly strong relationship with oil prices (Table 5).

Table 5. Correlationand $\mathrm{R}^{2}$ between ROACE oil prices during the period 2008-2019: oil majors.

\begin{tabular}{ccccc}
\hline & $\begin{array}{c}\text { Average } \\
2008-2019\end{array}$ & $\begin{array}{c}\text { Median } \\
2008-2019\end{array}$ & Correlation & \multirow{2}{*}{$\mathrm{R}^{2}$} \\
\hline Royal Dutch Shell & $9.2 \%$ & $8.0 \%$ & 0.74 & 0.54 \\
ExxonMobil & $16.0 \%$ & $16.3 \%$ & 0.77 & 0.60 \\
British Petroleum & $10.8 \%$ & $10.4 \%$ & 0.61 & 0.38 \\
Total & $13.3 \%$ & $12.4 \%$ & 0.62 & 0.38 \\
Chevron & $11.4 \%$ & $10.8 \%$ & 0.81 & 0.66 \\
ENI & $7.5 \%$ & $7.2 \%$ & 0.59 & 0.34 \\
\hline Average & $11.4 \%$ & $10.8 \%$ & 0.75 & 0.56 \\
Median & $11.1 \%$ & $10.6 \%$ & 0.73 & 0.53 \\
\hline
\end{tabular}

Source: Calculations of the authors based on the data from the annual reports of the selected companies

On average, about $50 \%$ of the profitability of large companies can be explained by the price of oil, and on an individual level, it ranges from $38 \%$ to $66 \%$.

To test the presence in the upstream segment for the profitability of oil companies in Central and Eastern Europe, we analyzed the correlation between profitability and the share of the upstream segment in total sales and total investment. Given the fact that the average oil price in 2019 was \$ 64 per barrel, which is close to the average price in the medium term (the average price over the past five years was around $\$ 57$ per barrel) and to the long-term price (average price for the last 20 years was 58.6 dollars per barrel.), in the analysis we used only indicators for 2019 (Table $6)$.

Table 6. Profitability and share of the upstream segment in sales and investments.

\begin{tabular}{cccc}
\hline ROACE & $\begin{array}{c}\text { Share of Up- } \\
\text { stream in Sales }\end{array}$ & $\begin{array}{c}\text { Share of Up- } \\
\text { stream in In- } \\
\text { vestments }\end{array}$ \\
\hline PKN Orlen & $10.5 \%$ & $1 \%$ & $11 \%$ \\
OMV & $10.0 \%$ & $24 \%$ & $63 \%$ \\
MOL & $7.6 \%$ & $11 \%$ & $16 \%$ \\
Hellenic Petroleum & $4.2 \%$ & $0 \%$ & $0 \%$ \\
OMV Petrom & $13.3 \%$ & $43 \%$ & $77 \%$ \\
INA & $3.5 \%$ & $19 \%$ & $32 \%$
\end{tabular}




\begin{tabular}{cccc} 
Petrol & $9.1 \%$ & $0 \%$ & $0 \%$ \\
NIS & $5.0 \%$ & $19 \%$ & $51 \%$ \\
\hline Average & $7.9 \%$ & $14.5 \%$ & $31.2 \%$ \\
Median & $8.3 \%$ & $14.6 \%$ & $23.9 \%$ \\
\hline Correlation & & 0.41 & 0.40 \\
R2 & & 0.15 & 0.16 \\
\hline
\end{tabular}

Source: Calculations of the authors based on the data from the annual reports of thselected companies

The results show a not very strong correlation, while the presence in the oil and gas upstream segment is significant, but only $15-16 \%$ of profitability is explained by this. The most profitable company is OMV Petrom, which is focused on upstream to a large extent. However, PKN Orlen and Petrol, which have a relatively small upstream segment or do not have it at all, also have relatively high profitability. With a decrease in prices by $10 \%$ (from 64 U.S. dollars per barrel) to medium and longterm average prices of 57-58 U.S. dollars per barrel, this gap would narrow even further. In 2017, when the average price was \$ 54 per barrel, the ROACE of OMV Petrom, PKN Orlen, and Petrol were $9.6 \%, 19.9 \%$, and $7.5 \%$, respectively.

\section{Conclusion}

Analyzing financial indicators for the period 2008-2019 we showed that CEE oil companies have increased their profitability, especially over the past three years, while continuing to invest significantly. Some of the reasons that contributed to this trend are the stabilization of oil prices to the level of 55-70 U.S. dollars per barrel, increased efficiency, and expansion of their portfolio to other energy segments as a result of relatively high investments.

Unlike major world oil companies, the volatility of crude oil prices significantly less impact on the profitability and investments of CEE oil companies. This can be explained by the fact that (1) many of them in the period 2008-2019 invested in increasing the company's efficiency, which led to increased profitability, and (2) CEE oil companies are less exposed to the upstream segment, which is very sensitive to fluctuations in crude oil prices.

In the upstream segment, there is a decrease in profitability as a result of lower crude oil prices (which will be even more depreciated in 2020 due to a collapse in the global oil market), and additional negative consequences for CEE oil companies' upstream segment are associated with low availability of reserves since this region is one of the poorest regionsin terms of hydrocarbons in Europe. Questions about the further role of the upstream segment should be answered at the individual company level depending on: (1) expectations related to the price of crude oil, (2) the possibility of acquiring reserves under favorable conditions, (3) the competitiveness of other business segments in which CEE oil companies have recently invested, such as petrochemicals, electricity and renewable energy, supported by government subsidies (profitability of upstream compared to other business segments), and (4) preferences of the companies related security of supply. All of these aspects deserve additional research. 


\section{References}

1. B. Fattouh, R. Poudineh, R. West, 2018. The Rise of Renewables and Energy Transition: What Adaptation Strategy for Oil Companies and Oil-Exporting Countries? The Oxford Institute for Energy Studies Paper, 19 (2018)

2. M. Pickl, The Renewable Energy Strategies of Oil Majors - From Oil to Energy. Energy Strategy Reviews, 26 (2019)

3. V.V. Yurak, A.V. Dushin, L.A. Mochalova, Sustainable development: scenarios for the future, Journal of Mining Institute, 242, 242 (2020). DOI: 10.31897/PMI.2020.2.242

4. P. Tcvetkov, A. Cherepovitsyn, S. Fedoseev, Public Perception of Carbon Capture and Storage: A State-of-the-Art-Review, Heliyon, 5 (2019).

5. N. Romasheva, A. Ilinova, CCS Projects: How Regulatory Framework Influences Their Deployment, Resources, 8 (2019).

6. E. Katysheva. Use of industry 4.0 tools To increase the efficiency of geological exploration works In oil and gas complex. Journal of Advanced Research in Dynamical and Control Systems, 12, 1347 (2020).

7. J. Luebeck, D. Petrov, Use of investment project implementation mechanism under production sharing agreement for the development of oil and gas, European Research Studies Journal, 21, 650 (2018).

8. G. Darko, J. Kruger, Determinants of Oil Price Influence on Profitability Performance of Oil and Gas Companies: A Panel Data Perspective, International Journal of Economics, Commerce, and Management, 12 (2018).

9. A. Dayanandan, H. Donker, Oil prices and accounting profits of oil and gas companies, International Review of Financial Analysis, 20(5) (2011).

10. A. P. Putra, L. Lahindah, L. Rismadi, Financial Performance Analysis Before and After Global Crisis (Case Study in Indonesian Oil and gas Sector for the Period of 2006-2011). Review of Integrated Business and Economic Research,3(1), 42 (2018).

11. R. Pirog, Financial Performance of the Major Oil Companies, 2007-2011, Congressional Research Service, (2012).

12. W. Wattanatorn, T. Kanchanapoom, Oil Prices and Profitability Performance: Sector Analysis, Procedia Social and Behavioral Sciences, 40, 763 (2012).

13. S. Isakov, N. K. Yilmaz, Performance Evaluation of Major Integrated Oil \& Gas Companies, Journal of Economics, Commerce, and Management, III (2015).

14. M. Ahmadi, M. Manera, M. Sadeghzadeh, The Investment-Uncertainty Relationship in the Oil and Gas Industry, Resources Policy, 63 (2019) 